\title{
Plasmodium ovale: a case of not-so-benign tertian malaria
}

\author{
Kathy-Anne Strydom ${ }^{1 *}$, Farzana Ismail ${ }^{1}$ and John Frean ${ }^{2,3}$
}

\begin{abstract}
Severe malaria is most commonly associated with Plasmodium falciparum. Plasmodium vivax is increasingly recognized as being capable of causing severe disease. In contrast, Plasmodium ovale is considered as a cause of benign disease and evidence supporting the occurrence of severe or complicated ovale infection is rare. This report describes a case of severe $P$. ovale infection in a patient presenting with jaundice, respiratory distress, severe thrombocytopenia, petechiae, and hypotension. He had no apparent underlying risk factors for severe disease.
\end{abstract}

Keywords: Plasmodium ovale, Severe, Malaria, Infection

\section{Background}

Malaria is the most important parasitic disease of man [1]. According to the World Health Organization (WHO) an estimated 3.3 billion people are at risk of malaria [2]. Annually there are over 200 hundred million clinical cases of malaria with an estimated 660,000 deaths, $90 \%$ of which occur in sub-Saharan Africa, where children under five years are most severely affected [2].

Disease in humans is caused by five species of apicomplexan parasites belonging to the genus Plasmodium [1]. Plasmodium falciparum is most commonly associated with severe disease [1-3]. Severe malaria is also known to occur with Plasmodium vivax and Plasmodium knowlesi $[1,4,5]$. Infection with Plasmodium malariae is generally benign, but has been associated with nephrotic syndrome and severe anaemia [3,6-8].

Although the clinical presentations of Plasmodium ovale and $P$. vivax infections largely overlap, severe disease due to $P$. ovale is extremely rare $[1,3,9]$. This case report describes an uncommonly severe case of ovale malaria in a patient with no apparent underlying risk factors for severe disease. The existing literature documenting severe or complicated presentations of $P$. ovale infection is reviewed.

\footnotetext{
* Correspondence: strydom.kathy@gmail.com

${ }^{1}$ National Health Laboratory Services, Tshwane Academic Division, Department of Medical Microbiology, University of Pretoria, Pretoria, South Africa

Full list of author information is available at the end of the article
}

\section{Case presentation}

A 42-year-old male, with no significant previous medical history, was referred by a general practitioner to the Steve Biko Academic Hospital, Pretoria, South Africa. The patient presented with fever, nausea and vomiting, general body pains and shortness of breath. He complained of feeling weak and tired for the last three weeks. In the preceding six months he had worked in two malaria-endemic regions: Kalia in the north-west region of Guinea, and most recently Mozambique, from where he had returned a month previously. He had not taken malaria chemoprophylaxis during his stay in these areas.

Upon physical examination the patient was awake and alert, with no signs of meningism. He was visibly jaundiced. Abdominal examination revealed a tender right upper quadrant, there were bilateral fine crepitations on auscultation of the lungs, and petechiae were visible on his upper and lower limbs. The patient was hypotensive (blood pressure $78 / 58 \mathrm{mmHg}$ ), tachycardic (pulse rate 110 per minute) and tachypnoeic (respiratory rate 28 per minute). The temperature was $39.5^{\circ} \mathrm{C}$. The chest $\mathrm{x}$-ray was unremarkable.

Laboratory evaluation showed a marked thrombocytopenia (platelets $23 \times 10^{9} / 1$ ), mildly deranged renal function (urea $13.2 \mathrm{mmol} / \mathrm{l}$, creatinine $157 \mu \mathrm{mol} / \mathrm{l}$ ) and liver function tests (total bilirubin $96 \mu \mathrm{mol} / \mathrm{l}$, alanine transaminase $43 \mathrm{U} / \mathrm{l}$, aspartate transaminase $74 \mathrm{U} / \mathrm{l}, \gamma$-glutamyltransferase $66 \mathrm{U} / \mathrm{l}$ ). The patient had markedly elevated inflammatory markers (C-reactive protein $121.7 \mathrm{mg} / \mathrm{l}$ and procalcitonin $105.6 \mu \mathrm{g} / \mathrm{l}$ ). 
The diagnosis of malaria was made by microscopic examination of Giemsa-stained blood smears, showing characteristic $P$. ovale parasites (Figure 1). The parasitaemia was $1.4 \%$. Rapid diagnostic tests for $P$. falciparum antigen (histidine-rich protein 2 ) were repeatedly negative. Mixed Plasmodium species infection was excluded and the diagnosis of $P$. ovale malaria was confirmed by multiplex PCR $[10,11]$.

The patient was admitted to high care and treated with a course of intravenous quinine $(600 \mathrm{mg}$ eight hourly) and doxycycline (100 mg twelve hourly). Ceftriaxone was added to cover for possible bacterial sepsis. The septic screen investigations, which comprised two sets of blood cultures and a urine culture, were negative. The timing of the blood cultures in relation to antibiotic administration is unclear.

The patient demonstrated a good clinical response to treatment, and he was stepped down to a general ward. Subsequent laboratory evaluations showed an improvement in full blood count, renal and liver functions as well as inflammatory markers, which returned to normal before discharge. Primaquine, $30 \mathrm{mg}$ orally for 14 days was administered to eradicate hypnozoites and prevent possible relapses.

\section{Discussion}

Endemic transmission of $P$. ovale is traditionally described as limited to sub-Saharan Africa and the islands of the western Pacific [9]. Infections with $P$. ovale have also been documented from India, the Middle East and parts of Southeast Asia [6,9]. Two non-recombining sympatric forms of $P$. ovale occur globally [12]. Plasmodium ovale curtisi (classic type) and Plasmodium ovale wallikeri (variant type) have been proposed as two distinct species $[12,13]$.

Much of what is currently known regarding the epidemiology of $P$. ovale is based upon surveys utilising light microscopy as diagnostic tool [6]. From these surveys, the prevalence of $P$. ovale is generally considered to be low and ranges between $3-5 \%$ and greater than $10 \%$ in areas of West and Central Africa [6]. The utility of light microscopy is limited by difficulties in distinguishing between $P$. ovale and $P$. vivax in smears, as well as the low parasitaemias characteristic of $P$. ovale infection. In addition, immunochromatography-based rapid diagnostic tests display poor sensitivity for the detection of $P$. ovale infection $[14,15]$. This may lead to underestimating the true burden of disease as is evident when more sensitive diagnostic modalities, such as
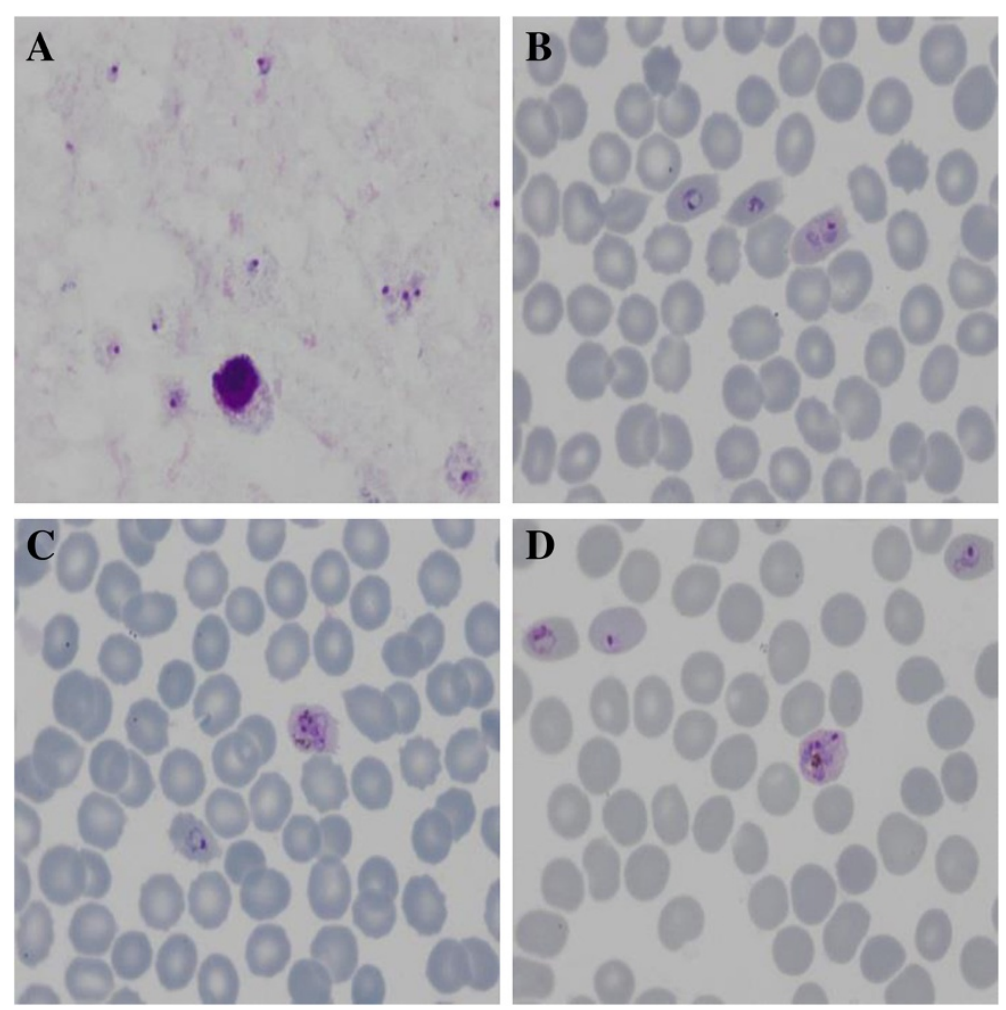

Figure 1 Giemsa-stained thick and thin smears. A. Trophozoites of P. ovale in a Giemsa-stained thick smear. B. Trophozoites and C, D. Trophozoites and immature schizonts of $P$. ovale in a Giemsa-stained thin film. Note slightly enlarged, fimbriated and oval-shaped infected red blood cells, with James' dots. 
Table 1 Summary of published cases of severe and complicated $P$. ovale infection

\begin{tabular}{|c|c|c|c|c|c|c|c|c|c|c|}
\hline Reference & $\begin{array}{l}\text { Patient } \\
\text { age }\end{array}$ & Gender & Medical history & Travel history & Prophylaxis & $\begin{array}{l}\text { Time to } \\
\text { presentation }\end{array}$ & Parasitaemia & $\begin{array}{l}\text { WHO or other } \\
\text { severity criteria }\end{array}$ & Treatment & Outcome \\
\hline This case report & $42 \mathrm{yr}$ & Male & None & $\begin{array}{l}\text { Kalia, Guinea: } \\
6 \text { months ago } \\
\text { Mozambique: } \\
1 \text { month ago }\end{array}$ & None & $1-6$ months & $1.4 \%$ & $\begin{array}{l}\text { Jaundice, } \\
\text { respiratory distress, } \\
\text { hypotension, } \\
\text { incipient bleeding }\end{array}$ & $\begin{array}{l}\text { IV quinine, } 14 \text { days } \\
\text { primaquine }\end{array}$ & Recovered \\
\hline Lee et al. [16] & $31 \mathrm{yr}$ & Female & None & Ghana & Mefloquine & 10 months & $0.1 \%$ & ARDS & $\begin{array}{l}\text { Chloroquine, } 14 \text { days } \\
\text { primaquine }\end{array}$ & Recovered \\
\hline Rojo Marcos et al. [17] & $43 \mathrm{yr}$ & Male & Hypertensive, diabetic & Nigeria & None & $N / S$ & $6,000 / \mu \mathrm{L}$ & ARDS & $\begin{array}{l}\text { Chloroquine, } 14 \text { days } \\
\text { primaquine }\end{array}$ & Recovered \\
\hline Haydoura et al. [18] & $46 \mathrm{yr}$ & Female & $\begin{array}{l}\text { Methylenetetrahydrofolate } \\
\text { reductase mutation with } \\
\text { secondary portal vein } \\
\text { thrombosis }\end{array}$ & $\begin{array}{l}\text { Acquired by } \\
\text { transfusion }\end{array}$ & N/A & $\begin{array}{l}1 \text { month } \\
\text { following } \\
\text { transfusion }\end{array}$ & $1.11 \%$ & ARDS & $\begin{array}{l}\text { IV quinine and } \\
\text { doxycycline, } 14 \text { days } \\
\text { primaquine }\end{array}$ & Recovered \\
\hline Roze et al. [19] & $24 \mathrm{yr}$ & Male & Tuberous sclerosis & Chad, Ivory Coast & Doxycycline & 1 year & $0.1 \%$ & ARDS & $\begin{array}{l}\text { Chloroquine then } \\
\text { changed to quinine }\end{array}$ & Recovered \\
\hline Lau et al. [20] & $59 \mathrm{yr}$ & Male & None & $\begin{array}{l}\text { Victoria Island, } \\
\text { Nigeria }\end{array}$ & Mefloquine & 6 months & $0.18 \%$ & $\begin{array}{l}\text { ARDS, acute renal } \\
\text { failure, metabolic } \\
\text { acidosis }\end{array}$ & $\begin{array}{l}\text { Chloroquine plus } \\
\text { primaquine, } \\
\text { changed to quinine, } \\
\text { then artesunate }\end{array}$ & Demised \\
\hline Hashimi et al. [21] & $31 \mathrm{yr}$ & Male & $\begin{array}{l}\text { Previous pulmonary } \\
\text { tuberculosis ( } 20 \text { years ago) }\end{array}$ & $\begin{array}{l}\text { Democratic } \\
\text { Republic of } \\
\text { Congo }\end{array}$ & N/S & 7 months & $0.2 \%$ & ARDS & IV quinine & Demised \\
\hline Facer et al. [23] & $51 \mathrm{yr}$ & Female & N/S & Ghana & None & 12 days & $1.8 \%$ & Splenic rupture & None & Demised \\
\hline Patel et al. [24] & $42 \mathrm{yr}$ & Male & $N / S$ & $\begin{array}{l}\text { South and } \\
\text { Central Africa }\end{array}$ & $\begin{array}{l}\text { Hydroxychloroquine, } \\
\text { discontinued during } \\
\text { travel }\end{array}$ & 18 months & $N / S$ & Splenic rupture & $\begin{array}{l}\text { Chloroquine and } \\
\text { primaquine }\end{array}$ & Recovered \\
\hline Cinquetti et al. [25] & $34 \mathrm{yr}$ & Male & None & $\begin{array}{l}\text { Senegal 2002, } \\
\text { Ivory Coast } 2004\end{array}$ & Doxycycline & $2-4$ years & $0.001 \%$ & Splenic infarction & IV quinine & Recovered \\
\hline
\end{tabular}


PCR-based methods targeting small subunit rRNA, are employed [6].

Plasmodium ovale is known to cause mild disease with a low parasitaemia $[6,9]$. Literature describing severe or complicated cases of $P$. ovale infection is limited. These rare reports include six cases complicated by acute respiratory distress syndrome (ARDS)(one of which further complicated by renal failure and metabolic acidosis), two cases of splenic rupture, and a single case of splenic infarction [16-25]. Clinical and therapeutic data for these cases are shown in Table 1.

The current WHO treatment guidelines for severe malaria recommend intravenous (IV) artesunate for the treatment of severe malaria due to all Plasmodium species [26]. Intravenous artesunate is currently not registered in South Africa for clinical use and is only available for named patients on application under Section 21 of the Medicines and Related Substances Act, usually at selected sentinel hospitals through the current artesunate access programme. The patient discussed in this case report was treated with IV quinine, which according to the current South African treatment guidelines, is still the treatment of choice for severe malaria in adult patients if IV artesunate is not readily available [27].

The pathophysiology of $P$. falciparum as the leading cause of severe malaria has been examined extensively. Various parasite, host, geographic and social factors contribute to severe disease manifestations; however, sequestration of mature parasitized red blood cells is considered to be the key pathogenic event $[28,29]$.

Plasmodium vivax, long considered to cause benign infection, is increasingly recognised as a cause of severe malaria $[30,31]$. Similar to $P$. falciparum infection, multiple factors contribute to severe disease [30]. Evidence is emerging that $P$. vivax infected red blood cells can also cytoadhere and sequestrate in the microvasculature, but to a lesser extent than P. falciparum [32]. It remains to be elucidated to what degree sequestration contributes to severe disease manifestations in vivax infections [30,32].

The pathophysiological correlates and risk factors for severe $P$. ovale infection are not yet fully established. Reports of severe ovale infection remain rare; however, when the diagnostic difficulties both in the detection of a low parasitaemia and distinguishing $P$. ovale from $P$. vivax, based on traditional light microscopy is taken into account, severe cases of ovale malaria may actually be underreported.

\section{Consent}

Verbal consent was obtained from the patient; however, due to his unavailability, written consent could not be obtained. Thus, ethical approval was obtained from the University of Pretoria Ethics Committee. The letter of approval from the Committee is available for review.

\section{Competing interests}

The authors have no competing interests to declare.

\section{Authors' contributions}

KA liaised with clinician regarding management of patient, collection of clinical information, drafting of manuscript. Fl reviewed manuscript. JF reviewed manuscript, confirmed identification of $P$. ovale and gave final approval for publication. All authors read and approved the final manuscript.

\section{Acknowledgements}

We thank Desiree du Plessis for the PCR testing.

\section{Author details}

${ }^{1}$ National Health Laboratory Services, Tshwane Academic Division, Department of Medical Microbiology, University of Pretoria, Pretoria, South Africa. ${ }^{2}$ Centre for Opportunistic, Tropical and Hospital Infections, National Institute for Communicable Diseases, Johannesburg, South Africa. ${ }^{3}$ Wits Research Institute for Malaria, School of Pathology, Faculty of Health Sciences, University of the Witwatersrand, Johannesburg, South Africa.

Received: 12 December 2013 Accepted: 2 March 2014

Published: 10 March 2014

\section{References}

1. Cook GC, Zumla Al: Malaria. In Manson's Tropical Diseases. 22nd edition. Edited by Cook GC, Zumla Al. London: Saunders; 2009:1201-1300.

2. World Health Organization: 10 Facts on Malaria. Geneva: WHO; 2013. Available: http://www.who.int/features/factfiles/malaria/en/index.html Accessed June 32013.

3. Garcia LS: Malaria. Clin Lab Med 2010, 30:93-129.

4. Price RN, Douglas NM, Anstey NM: New developments in Plasmodium vivax malaria: severe disease and the rise of chloroquine resistance. Curr Opin Infect Dis 2009, 22:430-435.

5. Baird JK: Evidence and implications of mortality associated with acute Plasmodium vivax malaria. Clin Microbiol Rev 2013, 26:36-57.

6. Mueller I, Zimmerman PA, Reeder JC: Plasmodium malariae and Plasmodium ovale - the 'bashful' malaria parasites. Trends Parasitol 2007, 23:278-283.

7. Collins WE, Jeffery GM: Plasmodium malariae: parasite and disease. Clin Microbiol Rev 2007, 20:579-592.

8. Douglas NM, Lampah DA, Kenangalem, Simpson JA, Poespoprodjo JR, Sugiarto P, Anstey NM, Price RN: Major burden of severe anemia from non-falciparum malaria species in Southern Papua: a hospital-based surveillance study. PLoS Med 2013, 10:e1001575.

9. Collins WE, Jeffery GM: Plasmodium ovale: parasite and disease. Clin Microbiol Rev 2005, 18:570-581.

10. Padley $\mathrm{D}, \mathrm{Moody} \mathrm{AH}$, Chiodini $\mathrm{PL}$, Saldanha J: Use of a rapid, single-round, multiplex PCR to detect malarial parasites and identify the species present. Ann Trop Med Parasitol 2003, 97:131-137.

11. Du Plessis D, Poonsamy B, Frean J: Validation of a malaria multiplex PCR for detection of malaria species in the Parasitology Reference Laboratory, NICD. NICD-NHLS Commun Dis Surveill Bull 2012, 10:33-35.

12. Sutherland CJ, Tanomsing N, Nolder D, Oguike M, Jennison C, Pukrittayakamee S, Doledcek C, Hien T,, Do Rosario VE, Arez AP, Pinto J, Michon P, Escalante AA, Nosten F, Burke M, Lee R, Blaze M, Otto TD, Barnwell JW, Pain A, Williams J, White NJ, Day NPJ, Snounou G, Lockhart PJ, Chiodini PL, Imwong M, Polley SD: Two non-recombining sympatric forms of the human malaria parasite Plasmodium ovale occur globally. $J$ Infect Dis 2010, 201:1544-1550.

13. Oguike MC, Betson M, Burke M, Nolder D, Stothard JR, Kleinschmidt I, Proietti C, Bousema T, Ndounga M, Tanabe K, Ntege E, Culleton R, Sutherland CJ: Plasmodium ovale curtisi and Plasmodium ovale wallikeri circulate simultaneously in African communities. Int J Parasitol 2011, 41:677-683.

14. Talman AM, Duval L, Legrand E, Hubert V, Yen S, Bell D, Le Bras J, Ariey F, Houze S: Evaluation of the intra- and inter-specific genetic variability of Plasmodium lactate dehydrogenase. Malar J 2007, 6:140.

15. Bigaillon C, Fontan E, Cavallo JD, Hernandez E: Ineffectiveness of the Binax NOW malaria test for the diagnosis of Plasmodium ovale malaria. $J$ Clin Microbiol 2005, 3:11. 
16. Lee $E Y$, Maguire JH: Acute pulmonary edema complicating ovale malaria. Clin Infect Dis 1999, 29:697-698.

17. Rojo-Marcos G, Cuadros-Gonzalez J, Mesa-Latorre JM, Culebras-Lopez AM, De Pablo-Sanchez R: Case report: acute respiratory distress syndrome in a case of Plasmodium ovale malaria. Am J Trop Med Hyg 2008, 79:391-393.

18. Haydoura S, Mazboudi O, Charafeddine K, BouakI I, Baban TA, Taher AT, Kanj SS: Transfusion-related Plasmodium ovale malaria complicated by acute respiratory distress syndrome (ARDS) in a non-endemic country. Parasitol Int 2011, 60:114-116.

19. Roze B, Lambert Y, Gelin E, Geffroy F, Hutin P: Plasmodium ovale malaria severity. Med Mal Infect 2011, 41:213-220.

20. Lau YL, Lee WC, Tan LH, Kamarulzaman A, Syed Omar SF, Fong MY, Cheong FW, Mahmud R: Acute respiratory distress syndrome and acute renal failure from Plasmodium ovale infection with fatal outcome. Malar J 2013, 12:389.

21. Hachimi MA, Hatim EA, Moudden MK, Elkartouti A, Errami M, Louzi L, Hanafi $S M$, Mahmoudi A: The acute respiratory distress syndrome in malaria: is it always the prerogative of Plasmodium falciparum? Rev Pneumol Clin 2013, 69:283-286

22. Imbert P, Buffet PA RC: Pathological rupture of the spleen in malaria: analysis of 55 cases (1958-2008). Travel Med Infect Dis 2009, 7:147-159.

23. Facer CA, Rouse D: Spontaneous splenic rupture due to Plasmodium ovale malaria. Lancet 1991, 338:896.

24. Patel MI: Spontaneous rupture of a malarial spleen. Med J Aust 1993, 159:836-837.

25. Cinquetti G, Banal F, Rondel C, Plancade D, De Saint Roman C, Adriamanantena D, Ragot C, Vedy S, Graffin B: Splenic infarction during Plasmodium ovale acute malaria: first case report. Malar J 2010, 9:288.

26. WHO: Management of Severe Malaria. Geneva: World Health Organization; 2012. Available: http://apps.who.int/iris/bitstream/10665/79317/1/ 9789241548526_eng.pdf Accessed February 2014.

27. National Department of Health: Guidelines for the Treatment of Malaria in South Africa. Pretoria: National Department of Health; 2010. Available: http:// www.malaria.org.za/Malaria_Risk/Treatment/guidelines2010.pdf Accessed February 2014

28. Miller LH, Baruch DI, Marsh K, Doumbo OK: The pathogenic basis of malaria. Nature 2002, 415:673-679.

29. Beeson JG, Brown GV: Pathogenesis of Plasmodium falciparum malaria: the roles of parasite adhesion and antigenic variation. Cell Mol Life Sci 2002, 59:258-271.

30. Anstey NM, Russel B, Yeo TW, Price RN: The pathophysiology of vivax malaria. Trends Parasitol 2009, 25:220-227.

31. Singh H, Parakh A, Basu S, Rath B: Plasmodium vivax malaria: is it actually benign? J Infect Public Health 2011, 4:91-95.

32. Carvalho BO, Lopes SCP, Nogueira PA, Orlandi PP, Bargieri DY, Blanco YC, Mamoni R, Leite JA, Rodrigues MM, Soares IS, Oliveira TR, Wunderlich G, Lacerda MVG, Del Portillo HA, Araujo MOG, Russel B, Suwanarusk R, Snounou G, Renia L, Costa FTM: On the cytoadhesion of Plasmodium vivax-infected erythrocytes. J Infect Dis 2010, 202:638-647.

doi:10.1186/1475-2875-13-85

Cite this article as: Strydom et al: Plasmodium ovale: a case of not-so-benign tertian malaria. Malaria Journal 2014 13:85.

\section{Submit your next manuscript to BioMed Central and take full advantage of:}

- Convenient online submission

- Thorough peer review

- No space constraints or color figure charges

- Immediate publication on acceptance

- Inclusion in PubMed, CAS, Scopus and Google Scholar

- Research which is freely available for redistribution

Submit your manuscript at www.biomedcentral.com/submit
Ciomed Central 